\title{
Respiratory Oxygen Response and Respiratory Quotient of Apple Stem Sections during Chilling
}

\author{
Eric Young ${ }^{1}$ \\ Department of Horticultural Science, North Carolina State University, Raleigh, NC 27695 \\ Additional index words. budbreak, bud dormancy, Malus domestica
}

\begin{abstract}
During natural leaf abscission, 2-year-old potted apple trees (Malus domestica Borkh. cv. MM.111 EMLA) were placed in a room at $6 \mathrm{C}$ for chilling $[0,600,900$, or 1400 chilling units $(\mathrm{CU})]$. After each chilling treatment, respiration of shoot segments was measured as $\mathrm{CO}_{2}$ evolved and $\mathrm{O}_{2}$ consumed at $22 \mathrm{C}$ in several $\mathrm{O}_{2}$ concentrations. Respiration increased with oxygen concentration after all $\mathrm{CU}$ treatments. Carbon dioxide evolved at the several $\mathrm{O}_{2}$ levels did not show a pattern related to $\mathrm{CU}$, but $\mathrm{O}_{2}$ consumed decreased at a decreasing rate with additional $\mathrm{CU}$. Respiratory quotient was $<1$ at 0 and $600 \mathrm{CU}$ and equal to 1 at 900 and $1400 \mathrm{CU}$, indicating a possible shift in respiratory substrate with chilling.
\end{abstract}

Deciduous fruit trees require a minimum amount of chilling (410C) for release from dormancy (Perry, I97 1; Samish, 1954) and initiation of growth. This transition from the beginning of dormancy to active growth is accompanied by many metabolic changes, some of which are temperature-regulated. Changes in DNA and RNA levels (Barskaya and Oknina, 1959), protein content (Titus and Kang, 1982; Wang et al., 1985), hormone levels (Wood, 1983), and polyamincs (Wang et al., 1985) have been reported. Carbohydrate levels also change as reserves arc broken down and mobilized for new shoot and root growth (Hansen, 1971: Quinlan, 1969).

Compared to herbaceous plants, woody perennials have a high concentration of degradable carbohydrate reserves (Priestly, 1962), which are unlikely to be exhausted during dormancy under normal circumstances. Nevertheless, many trees' roots and shoots demonstrate a marked seasonal fluctuation in respiration rate when measured at constant temperature (Cox, 1975; Shiroya et al.. 1966; Strain, 1969). Wang et al. (1991) found a significant increase in respiration of apple buds induced to break dormancy by thidiazuron compared to untreated buds: also, respiration of apple root and shoot tissue increased during forcing at $23 \mathrm{C}$ only after trees had been fully chilled (Young et al., 1987). Studies also have shown that the $\mathrm{Q}_{10}$ and energy of activation (EA) for shoot respiration, measured after forcing at $20 \mathrm{C}$, decreased with increased chilling given before forcing (Young, 1990). One possible explanation for the observed decrease in respiratory EA after chilling is a shift in the metabolic source of the $\mathrm{CO}_{2}$ evolved. The EA measured was an average for all pathways that evolved $\mathrm{CO}_{2}$, rather than mitochondrial respiration per se. These results indicate a possible change in $\mathrm{C}$ metabolism associated with dormancy release, which may also mean a change in respiratory substrate. The ratio of $\mathrm{CO}_{2}$ evolved to $\mathrm{O}_{2}$ consumed in respiration (RQ) is an indication of the original substrate used in respiration. If glucose only is respired, RQ $=1$, organic acids yield an $R Q>1$, and fatty acids yield an RQ $<1$; e.g., stearic acid respiration results in $\mathrm{RQ}=0.7$, and with palmitic acid, RQ $=0.36$ (Noggle and Fritz, 1976).

The RQ in dormant pea ( Pisum sativum L.) seeds increases from 0.4 to between 0.7 and 0.8 as seeds develop toward germination (Obrucheva and Kovadlo, 1985), which is thought to be due to oxidation of storage lipids early in the dormancy period. A similar

Received for publication 25 June 1992. Accepted for publication 23 Nov. 1992. I acknowledge the valuable technical assistance of Robert Belding throughout this study. The cost of publishing this paper was defrayed in part by the payment of page charges. Under postal regulations, this paper therefore must be hereby marked advertisement solely to indicate this fact.

${ }^{1}$ Professor. situation occurs in dormant apple seeds (DawidowiczGrzegorzcwska, 1989). where degradation of lipid bodiesdepends on chilling, which is necessary for germination. The RQ in apple buds during dormancy has not been reported, but Lui et al. (1991) found that lipase activity in apple buds increased greatly as chilling progressed.

A recent study of low-oxygen storage of fully chilled, quiescent apple trees (Young and Blankenship, 1991) showed that $\mathrm{O}_{2}$ concentrations $<5 \%$, combined with $6.0 \mathrm{C}$, inhibited budbreak for up to 35 weeks with no detectable effects on subsequent shoot growth. It is not known how $\mathrm{O}_{2}$ level affects respiration during dormancy and whether or not any effects would change with changes in respiratory substrate.

The purposes of this study were 1) to measure respiration of apple shoot tissue during dormancy as both $\mathrm{CO}_{2}$ evolution and $\mathrm{O}_{2}$ consumption to calculate RQ values. and 2) to determine the effects of atmospheric $\mathrm{O}_{2}$ concentration on these respiration measures.

\section{Material and Methods}

Forty 1 -year-old rooted layers of Malling Merton 111 (MM. 111) apple [chilling requirement 1450 chill units (CU) (Hauagge and Cummins, 1991; Young and Werner, 1985)] were lifted from a commercial stoolbed (Treco, Woodburn, Ore.). All trees were pruned to $60 \mathrm{~cm}$ above the root collar, and all lateral branches were removed. Trees were potted in 3.5-liter containers in damp calcined clay (Turface) and placed in a room at $5 \pm 2 \mathrm{C}$. After each chilling treatment $(0,600,900$, or $1400 \mathrm{CU}), 10$ trees were removed and terminal shoots cut into four $10-\mathrm{cm}$ sections, excluding the top and bottom $10 \mathrm{~cm}$. One of each of these sections was placed in each of forty $100-\mathrm{ml}$ test tubes containing a piece of moist filter paper to prevent desiccation. Shoot sections were placed randomly into the various oxygen concentrations to randomize any variation due to acrotony and basitony. Groups of four test lubes were each thoroughly blushed with one of 10 gas mixtures containing $\mathrm{O}_{2}$ at $0.5 \%, 2 \%, 4 \%, 6 \%, 8 \%, 11 \%, 13 \%, 15 \%, 18 \%$, or $21 \%$ $\pm 0.5 \%$. Gas mixtures were made by metering compressed air $\left(0.03 \% \mathrm{CO}_{2}, 21 \% \mathrm{O}_{2}, 78 \% \mathrm{~N}_{2}\right)$ and compressed nitrogen $(99.5 \%$ $\mathrm{N}_{2}, 0.5 \% \mathrm{O}_{2}$ ) together in various ratios. The final mixtures were monitored each time the tubes were flushed. Tubes were then sealed with a rubber serum stopper and inverted into a pan of $22 \mathrm{C}$ water to prevent gas leaks and maintain a constant temperature. Shoot sections were equilibrated in these atmospheres for $4 \mathrm{~h}$, then tubes were reflushed with identical gas mixtures and sealed as before. A 1-ml gas sample was withdrawn through the serum 


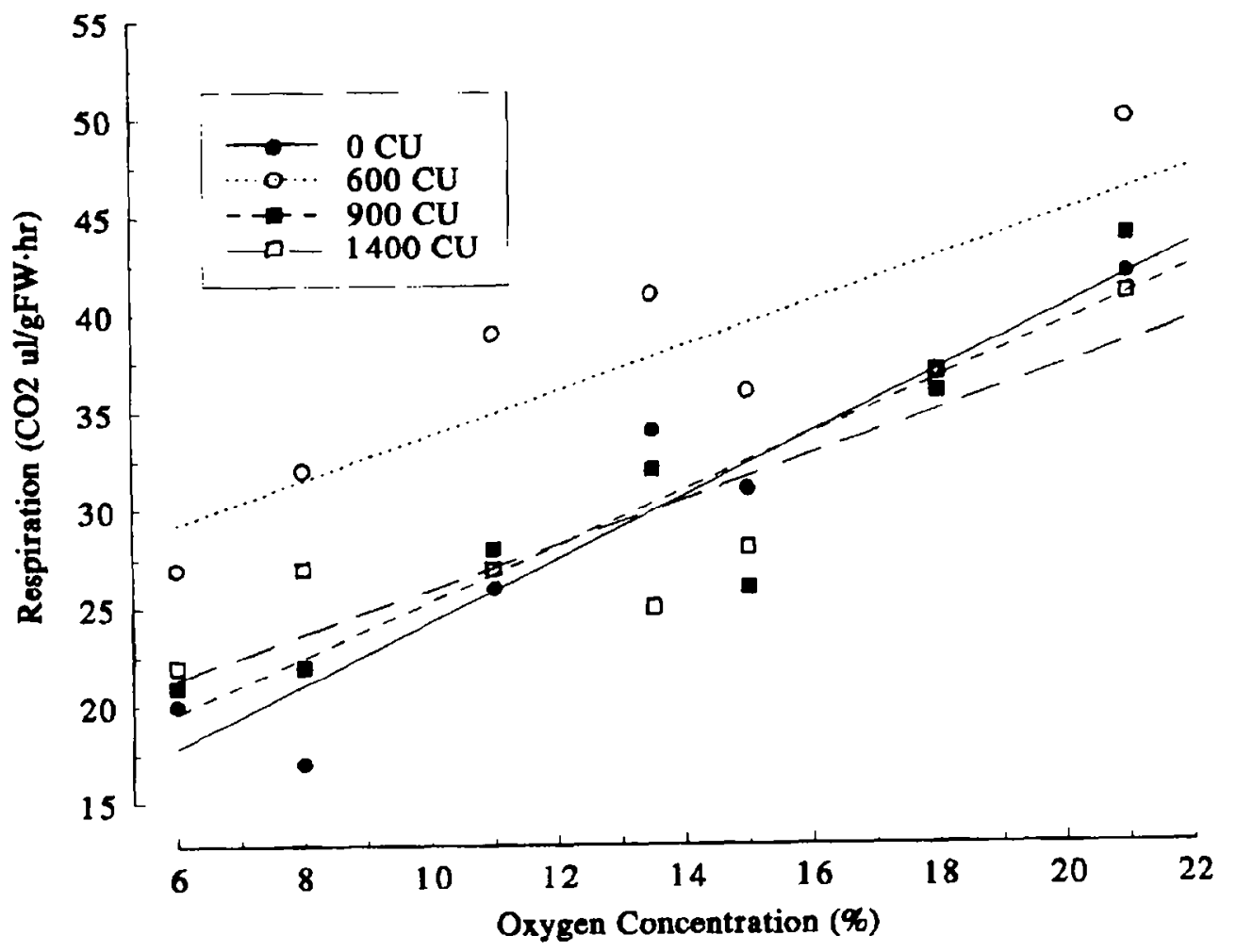

Fig. 1. Respiration at various atmospheric $\mathrm{O}_{2}$ concentrations as measured by $\mathrm{CO}_{2}$ evolution of $10 \mathrm{~cm}$-long apple shoot segments that had previously received chillin of $0,600,900$, or $1400 \mathrm{CU}$. Data shown are means of four replications. Linear regression equations arc as follows: $0 \mathrm{CU}, \mathrm{Y}=1.6 \mathrm{X}+8.5, r^{2}=0.92^{* *} ; 600 \mathrm{CU}, \mathrm{Y}$ $1.1 \mathrm{X}+23.0, r^{2}=0.70^{*} ; 900 \mathrm{CU}, \mathrm{Y}=1.4 \mathrm{X}+10.5, r^{2}=0.85^{* *}: 1400 \mathrm{CU}, \mathrm{Y}=0.9 \mathrm{X}+16.5, r^{2}=0.79 *$

stopper from each test tube immediately after resealing and after an additional $2 \mathrm{~h}$. Carbon dioxide and $\mathrm{O}_{2}$ levels were measured on a gas chromatograph using a molecular sieve $(13 \times)$ column at 50C with a thermal conductivity detector, with helium as a carrier gas. Fresh weight of each shoot section was determined after obtaining respiration measurements. Respiration was calculated as microliters of $\mathrm{CO}_{2}$ evolved and $\mathrm{O}_{2}$ consumed per gram fresh weight. The RQ was calculated as the ratio of $\mathrm{CO}_{2}$ evolved to $\mathrm{O}_{2}$ consumed per gram fresh weight. Polynomial regression analysis was applied to the rates of $\mathrm{CO}_{2}$ evolved and $\mathrm{O}_{2}$ consumed, and logarithmic regression analysis was used for the RQ data.

\section{Results and Discussion}

RQ values increased to between 3.0 and 5.5 for trees subjected to $\mathrm{O}_{2}$ concentrations $14 \%$ (data not shown), indicating that respiration had become anaerobic (Wills et al., 1981): therefore, only data for $\mathrm{O}_{2}$ between $6 \%$ and $21 \%$ are shown. Respiration, as measured by $\mathrm{CO}_{2}$ evolved, generally increased as atmospheric $\mathrm{O}_{2}$ increased across the range of concentrations used for all chilling treatments (Fig. 1). The rate of decrease in respiration appeared to show a slight parabolic curve between $18 \%$ and $8 \% \quad \mathrm{O}_{2}$; however, only the linear portion of the polynomial regression analysis was significant for each curve (Fig. 1). There were no significant differences due to chilling treatments in the response of $\mathrm{CO}_{2}$ evolution to $\mathrm{O}_{2}$ concentration (i.e., regression slopes were not significantly different). Trees receiving $600 \mathrm{CU}$ had somewhat higher respiration rates over the whole range than the rest (Fig. 1), although the regression intercept was not significantly different from that of the other chilling treatments.
Respiration as measured by $\mathrm{O}_{2}$ consumption decreased as $\mathrm{O}_{2}$ concentration decreased across the range of concentrations (Fig. 2). As in Fig. I, the data appeared to be curvilinear, particularly at $0 \mathrm{CU}$, but only the linear portion of a polynomial regression was significant. The apparent increase in respiration between $21 \%$ and $18 \% \mathrm{O}_{2}$ for the $0 \mathrm{CU}$ trees (Fig. 2) may have been due to unusually low respiration rates at $21 \% \quad \mathrm{O}_{2}$ rather than an actual increase as $\mathrm{O}_{2}$ decreased. The change in $\mathrm{O}_{2}$ consumption with $\mathrm{O}_{2}$ concentration, as measured by the slope of the regression lines (Fig. 2), decreased significantly as the trees were chilled from 0 to $600 \mathrm{CU}$ and 600 to 900 CU. No significant difference in $\mathrm{O}_{2}$ consumption was found between trees chilled for 900 and $1400 \mathrm{CU}$. These data indicate that apple shoot sections consume less $\mathrm{O}_{2}$ as they progress through chilling, and that the response curve of respiration to $\mathrm{O}_{2}$ concentration changes with chilling.

The RQ values did not change significantly at $\mathrm{O}_{2}$ concentrations between $21 \%$ and $15 \%$, but increased somewhat from $15 \%$ to $6 \%$ (Fig. 3). RQ in $21 \%$ to $15 \% \mathrm{O}_{2}$ was $\approx 0.25$ for trees that had received $0 \mathrm{CU}, 0.50$ for trees chilled $600 \mathrm{CU}$, and 1.00 for trees chilled 900 or $1400 \mathrm{CU}$ (Fig. 3). The RQ values indicate that these trees were using lipids as a significant portion of the substrate for respiration early in the dormancy period. Since the RQ values had increased to 1.0 after $900 \mathrm{CU}$. the primary respiratory substrate had probably changed to carbohydrates, such as sucrose, by that point in dormancy development.

The results presented here provide further indications that the change in respiratory energy of activation with chilling, reported previously (Young, 1990). is likely to be due to a change in the dominant respiratory pathway during chilling. This pattern could account for changes in energy of activation and RQ values for respiration of apple shoots during and after chilling. 


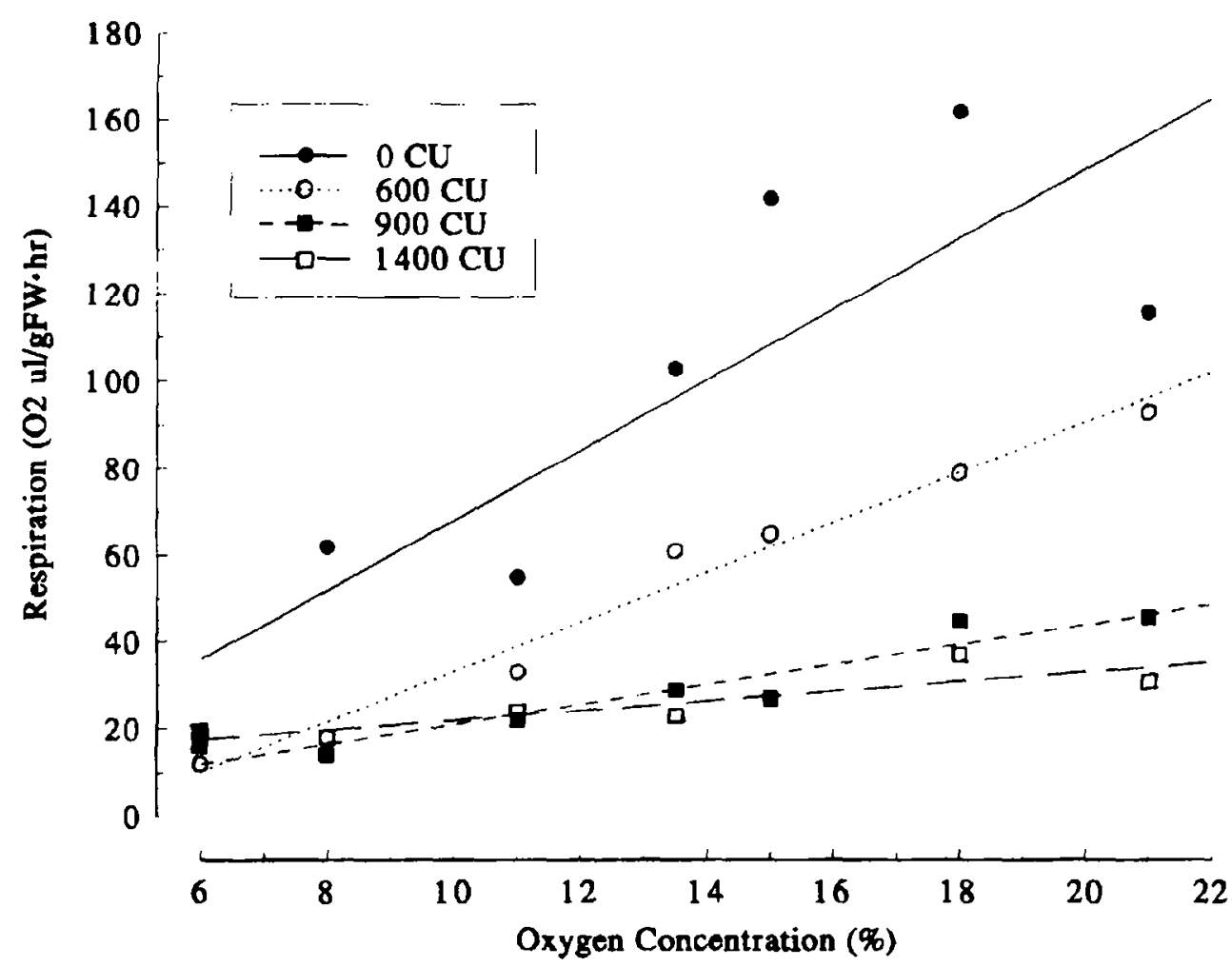

Fig. 2. Respiration at various atmospheric $\mathrm{O}_{2}$ concentrations as measured by $\mathrm{O}_{2}$ consumption of 10 -cm-long apple shoot segments that had previously received chilling of $0,600,900$, or $1400 \mathrm{CU}$. Data shown are means of four replications. I. inear regression equations are as follows: $0 \mathrm{CU}, \mathrm{Y}=8.1 \mathrm{X}-12.5, r^{2}=0.71^{*}$; $600 \mathrm{CU}, \mathrm{Y}=5.7 \mathrm{X}-24.4, r^{2}=0.97^{* *} ; 900 \mathrm{CU}, \mathrm{Y}=2.3 \mathrm{X}-1.9, r^{2}=0.91^{* *} ; 1400 \mathrm{CU}, \mathrm{Y}=1.1 \mathrm{X}+10.9, r^{2}=0.77^{*}$.

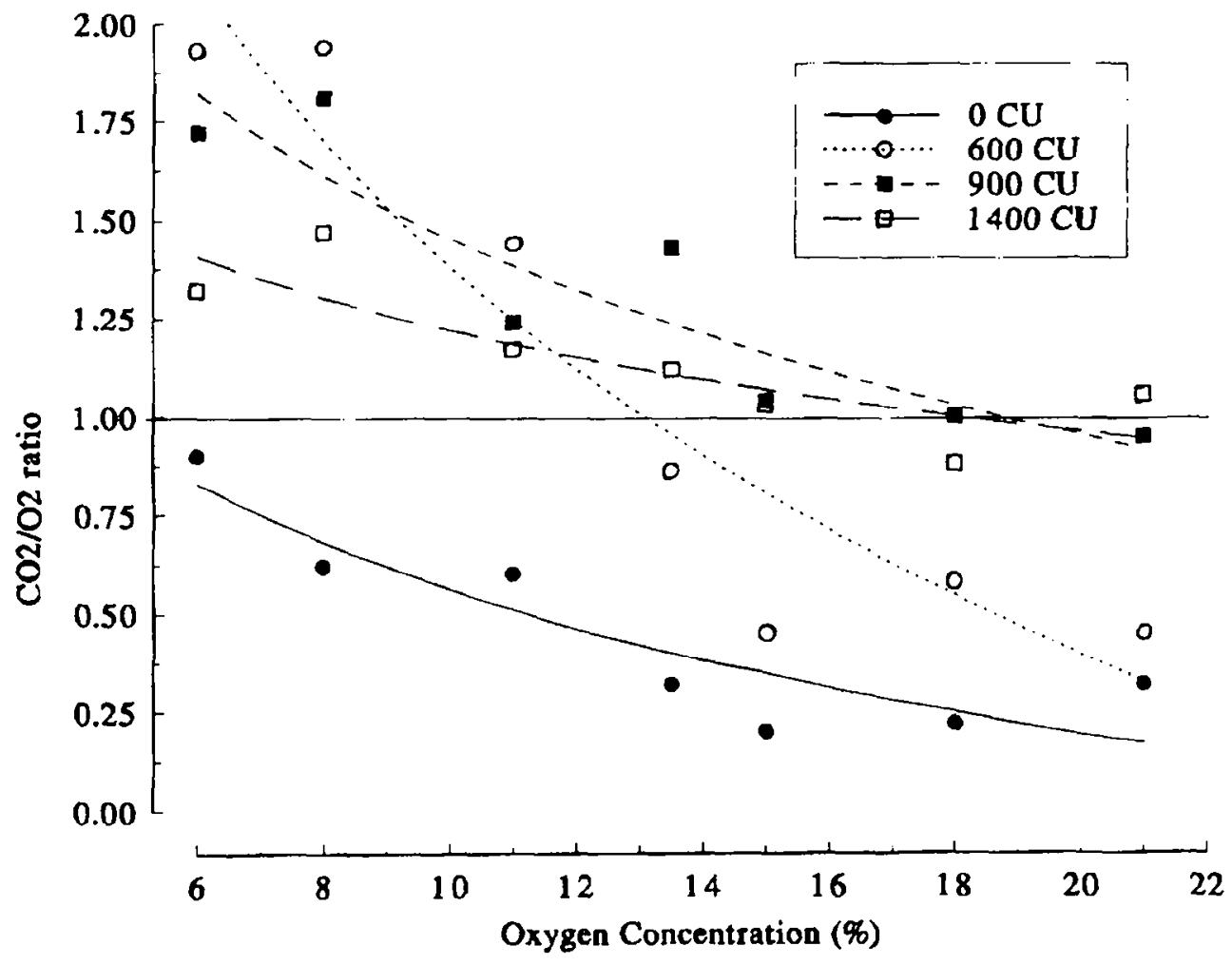

Fig. 3. Respiratory quotient at different atmospheric $\mathrm{O}_{2}$ concentrations of $10 \mathrm{~cm}$-long apple shoot segments that had previously received chilling of $0,600,900$, or $1400 \mathrm{CU}$. Data shown are means of four replications. Logarithmic regression equations are as follows: $0 \mathrm{CU}, \mathrm{Y}=1.8-0.5 \ln \mathrm{X}, \mathrm{r}^{2}=0.83^{* *} ; 600 \mathrm{CU}, \mathrm{Y}$ $=4.7-1.4 \ln \mathrm{X}, r^{2}=0.90^{* *} ; 900 \mathrm{CU}, \mathrm{Y}=3.1-0.7 \ln \mathrm{X}, r^{2}=0.83^{* *} .1400 \mathrm{CU}, \mathrm{Y}=2.1-0.4, r^{2}=0.71^{*}$. 


\section{Literature Cited}

Barskaya, E.N. and E.Z. Oknina. 1959. The role of nucleic acids in the growth processes and bud dormancy of fruit crops. Soviet Plant Physiol. 6:470-476.

Cox, T.L. 1975. Seasonal respiration rates of yellow-poplar roots by diameter classes. For. Sci. 21:185-190.

Dawidowicx-Grzegorzewska, A. 1989. Degradation of protein and lipid bodies during dormancy removal in apple seeds. J. Plant Physiol. 135:43-51.

Hansen, P. 1971. 14C-Studies on apple trees: VII. The early seasonal growth in leaves, flowers and shoots as dependent upon current photosynthates and existing reserves. Physiol. Plant. 25:469-473.

Hauagge, R. and J.N. Cummins. 1991. Phenotypic variation of length of bud dormancy in apple cultivars and related Malus species. J. Amer. Soc. Hort. Sci. 116:100-106

Lui, D., H.A. Norman, G.A. Stutte, and M. Faust. 1991. Lipase activity during endodormancy in leaf buds of apple. J. Amer. Soc. Hort. Sci. 116:689-692.

Noggle, G.R. and G.J. Fritz. 1976. Introductory plant physiology. Prentice Hall, Englewood Cliffs, N.J.

Obrucheva, N.V. and L.S. Kovadlo. 1985. Two stages of intensification in the respiration of germination pea seeds in proportion to increase of their hydration. Fiziol. Rast. 32:753-761.

Perry, T.O. 1971. Dormancy of trees in winter. Science 171:29-36.

Priestly, C.A. 1962. The location of carbohydrate resources within the apple tree. Proc. XVIth Intl. Hort. Congr. 3:319-327.

Quinlan, J.D. 1969. Mobilization of 14C in the spring following autumn assimilation of $14 \mathrm{CO}_{2}$ by an apple rootstock. J. Hort. Sci. 44: 107-I IO

Samish, R.M. 1954. Dormancy in woody plants. Annu. Rev. Plant Physiol. 5:183-204.
Shiroya, T., G.R. Lister, V. Slankis, G. Krotokov, and G.D. Nelson. 1966. Seasonal changes in respiration, photosynthesis, and translocation of 14C-labeled products of photosynthesis in young Pinus strobus L. plants. Ann. Bot. 30:81-91

Strain, B.R. 1969. Seasonal adaptations in photosynthesis and respiration in four desert shrubs growing in situ. Ecology 50:5111-513.

Titus, J.S. and S.M. Kang. 1982. Nitrogen metabolism, translocation. and recycling in apple trees. Hort. Rev. 4:204-246.

Wang, S.Y., M. Faust, and G.L. Steffens. 1985. Metabolic changes in cherry flower buds associated with breaking of dormancy in early and late blooming cultivars. Physiol. Plant. 65:89-94.

Wang, S.Y., H.J. Jiao, and M. Faust. 1991. Changes in metabolic enzyme activities during thidiazuron-induced lateral budbreak of apple. HortScience 26:171-173.

Wills, R.B.H., T.H. Lee, D. Graham, W.B. McGlasson, and E.G. Hall. 1981. Postharvest. AVI Publishing Co., Westport, Conn.

Wood, B.W. 1983. Changes in indolcacetic acid, abscisic acid, gibberellins, and cytokinins during bud break in pecan. J. Amer. Soc. Hort. Sci. 108:333-338

Young, E. 1990. Changes in respiration rate and energy ofactivation after chilling and forcing dormant apple trees. J. Amer. Soc. Hort. Sci. 115:809-814.

Young, E. and SM. Blankenship. 1991. Low oxygen delays budbreak of apple trees in greenhouse and prolongs storage life. HortScience 26:890891.

Young, E. and D.J. Werner. 1985. Chill unit and growing degree hour requirements for vegetative bud break in six apple rootstocks. J. Amer. Soc. Hort. Sci. 110:411-413.

Young, E., Y. Motomura, and CR. Unrath. 1987. Influence of root temperature during dormancy on respiration, carbohydrates, and growth resumption in apple and peach. J. Amer. Soc. Hort. Sci. 112:514-519. 